Originalni naučni rad

Primljen: 4. 11. 2016.

Revidirana verzija: 6. 2. 2017. UDK: 371.275:[378.6:351.74(497.11)

Prihvaćen: 9. 2. 2017.

doi: $10.5937 /$ nabepo22-12301

\title{
TREND OF CHANGES OF STUDENT RESULTS AT THE ACADEMY OF CRIMINALISTIC AND POLICE STUDIES ENTRANCE EXAM ${ }^{1}$
}

\author{
Radivoje Janković \\ Nenad Koropanovski \\ Academy of Criminalistic and Police Studies, Belgrade
}

\begin{abstract}
The aim of the research was to determine the trends of changes on the Academy of Criminalistic and Police Studies (ACPS) entrance exam. Furthermore, the paper is to find whether there are any differences between the sexes in the terms of the results of the entrance exam. 1.576 examinees participated in the research (621 female and 955 male), all of which entered the ACPS as the students of basic and vocational studies. The paper analyses their scores in all components of the exam: High School Achievements (HSA), General Knowledge Test (GKT), Serbian Language and Literature Test (SLLT), the Level of Basic Motoric Abilities development (BMA) and the overall number of points achieved on the test. The results were firstly analysed by applying the basic descriptive statistics procedure, which determined the equation of trend of changes and R-squared values. The existence of the general variability differences between groups was determined by using MANOVA, while for the determination of partial differences between pairs of variables the Bonferroni test was used. The
\end{abstract}

1 This paper is the result of the research on project: "Management of police organization in preventing and mitigating threats to security in the Republic of Serbia", which is financed and carried out by the Academy of Criminalistic and Police Studies, Belgrade - the cycle of scientific projects $2015-2019$. 
positive changes trend for both sexes in HSA and the negative one in SLLT were demonstrated. In females, a positive trend in BMA and a negative GKT trend were observed. However, an opposite effect was detected in males. Nevertheless, despite the different trends in individual tests, the overall number of points achieved on the entrance exam demonstrated a positive trend of changes in both populations. MANOVA results showed that the females had statistically better results in HSA, SLLT and BMA variables, but worse results in GKT. The overall result on the entrance examination taken into account, the females had statistically better scores by $3.31 \%$.

Keywords: police, selection, entrance examination, trend of changes.

\section{Introduction}

Selection and education are linked processes which bear the aim of securing competent staff, ${ }^{2}$ since better educated police academy graduates will likely make an impact on the job performance as future police officers. ${ }^{3}$ In other words, education is a prerequisite of efficient police work hence it has to begin with a quality candidate selection process. ${ }^{4}$ Because of this, the police candidates are obligated to fulfil predetermined conditions. In the further process of selection, their achievements in the tests are assessed, and the most qualified candidates are chosen. ${ }^{5}$ Moreover, the aim of the selection models is to eliminate the candidates whose characteristics or abilities are not acceptable for police work. ${ }^{6}$ Exactly because of such importance selection and education

\footnotetext{
2 B. Sanders, Maybe there's no such thing as a "good cop": Organizational challenges in selecting quality officers, Policing: An International Journal of Police Strategies \& Management, vol. 26, no. 2/2003, Bingley, pp. 313-328.

3 A. Chappell, Police academy training: comparing across curricula, Policing: An International Journal of Police Strategies \& Management, vol. 31, no. 1/2008, Bingley, pp. 36-56.

4 M. Dopsaj; M. Blagojević; G. Vučković, Normativno-selekcioni kriterijum za procenu bazično motoričkog statusa kandidata za prijem na studije Kriminalističko-policijske akademije u Beogradu, Bezbednost, vol. 49, no. 4/2007, Beograd, pp. 166-183.

5 G. A. Anderson; D. Plecas; T. Segger, Police officer physical ability testing: Re-validation a selection criterion, Policing: An International Journal of Police Strategies \& Management, vol. 24, no. 1/2001, Bingley, pp. 8-31. S. Annell; P. Lindfors; M. Sverke, Police selection implications during training and early career, Policing: An International Journal of Police Strategies \& Management, vol. 38, 2/2015, Bingley, pp. 221-238.

6 E. Metchik, An analysis of the "Screening out" model of police officer selection, Police Quarterly, vol. 2, no. 1/1999, pp. 79-95. K. A. Lonsway, Tearing down the wall: Problems with consistency, validity, and adverse impact of physical agility testing in police selection, Police Quarterly, vol. 6, no. 3/2003, London, pp. 237-277.
} 
have on the one hand, and the development, results monitoring and the possibility of correlating those with work efficiency have on the other, these are highly significant subject matters of all police organisations over the world. ${ }^{7}$ Although there are differences between selection models, weighted average and the police work types, the research so far has shown that the majority of the selection models usually consist of health check, cognitive abilities and personality testing, as well as the candidates' physical abilities check. ${ }^{8}$

The highest educational level for gaining the academic police officer vocation in the Republic of Serbia is through education at the Academy of Criminalistic and Police Studies (ACPS). Since the foundation of the ACPS in 2006, the entrance examination process has been modified. Only the High School Achievements remained equally valued and its share has always been $40 \%$ of the hypothetical maximum of points. Until 2012, the graded tests (e.g. geography, history, psychological test) have been changed as well as the physical ability and the psychological test thresholds. Since 2012, elimination check has been applied, which deals with whether a candidate fulfils the conditions regarding morphological features, namely adequate biological and psychological health. After this, the candidates are selected through a four-modelled system graded by points. The grade system comprises of High School Achievements (HSA), carrying a maximum of 40 points, and the tests in: General Knowledge (GKT), Serbian Language and Literature Test (SLLT), Basic Motoric Abilities (BMA). On each of the tests, the candidate may achieve a maximum of 20 points, which makes a potential maximum of 100 points. ${ }^{9}$

Earlier researches determined that, when compared to the policewomen, the policemen demonstrate more developed BMA. ${ }^{10}$ Because of this it is important for the selection criteria to be adjusted to the differences in sex in order to avoid discrimination. ${ }^{11}$ This is the reason for different norms for men and women at the ACPS in terms of entrance exam test results. The score of every candidate is assessed based on their positioning regarding the young and healthy population of both sexes in the Republic of Serbia. The overall

\footnotetext{
$7 \mathrm{~V}$. Lord, Swedish police selection and training: issues from a comparative perspective, Policing: An International Journal of Police Strategies \& Management, vol. 21, no. 2/1998, Bingley, pp. 280-292.

8S. Annell; P. Lindfors; M. Sverke, Opus citatum, pp. 221-238.

9 R. Janković, et al, Academy of criminalistic and police studies candidates' basic-motor skills in function of successful enter exam for basic academic studies, in: International Scientific Conference: Effects of Physical Activity Application to Anthropological Status With Children, Youth and Adults - Thematic conference proceedings of international significance, Faculty of Sport and Physical Educatin, Belgrade, Decembre 2013, pp. 316-322.

10 S. G. Anderson; D. Plecas, Predicting shooting scores from physical performance data, Policing: An International Journal of Police Strategies \& Management, vol. 23, no. 4/2000, Bingley, pp. 525-537. M. Strating, et al, A job-related fitness test for the Dutch police, Occupational Medicine, vol. 60, no. 4/2010, Oxford, pp. 255-260.

11 K. A. Lonsway, Opus citatum, pp. 237-277.
} 
number of points on the BMA part of the examination is determined as a total score of each of the 7 tests, ${ }^{12}$ which are adjusted by the factor coefficient compared to the overall observed population. ${ }^{13}$ In this way the level of physical fitness is generalized. ${ }^{14}$

According to White's research ${ }^{15}$ it was determined that writing and communication are two important skills that are prerequisites for good policing. Reading level is typically related to writing and communications abilities. Bearing these facts in mind, the achieved level of knowledge and official language kills assessed through the SLLT represents an important component thereby increasing its relevance to the recruitment, selection, and training processes. Police officers' job is predominantly linked to solving problems generated by people in a social community. A wide spectrum of knowledge regarding social affairs, their causes and consequences poses a significant basis for successful complex problem solving. Furthermore, the ability of making connections, divergent thinking, being creative and fast problem solving, known as fluid intelligence, is developed more rapidly if the level of already accumulated knowledge is higher. ${ }^{16}$ Because of the above mentioned, a higher level of knowledge demonstrated on GKT represents a better starting point for the final product at the end of the educational process.

An adequate selection of candidates at the beginning of the educational process and a well-planned educational program can lead to the desired output. ${ }^{17}$ It is also highly important for the whole system to be monitored and controlled so the potential flaws could be removed and, by doing so, the whole process of selection and education would be constantly enhanced. ${ }^{18}$ The goal of this paper is to determine the trends in changes of high school achievements, general knowledge test results and Serbian language skills, as well as

12 N. Koropanovski; R. Dimitrijevic; R. Jankovic, Trend of changes in motor abilities initial level in the male students of the Academy of Criminalistic and Police Studies, in: International Scientific Conference "Archibald Reiss Days", Academy of Criminalistic and Police Studies, Belgrade, 2016, pp. 136-143.

13 M. Dopsaj; M. Blagojević; G. Vučković, Opus citatum, pp. 166-183.

14 R. Janković; R. Dimitrijević, Stanje i mogućnosti unapređenja načina procene motoričkih sposobnosti u sistemu Ministarstva unutrašnjih poslova Republike Srbije, Kultura polisa, vol. 9, no. 1/2012, Novi Sad, pp. 419-435.

$15 \mathrm{M}$. White, Identifying Good Cops Early Predicting Recruit Performance in the Academy, Police Quarterly, vol. 11, no. 1/2008, London, pp. 27-49.

16 M. Batey; A. Furnham; X. Safiullina, Intelligence, general knowledge and personality as predictors of creativity, Learning and Individual Differences, vol. 20, no. 5/2010, Amsterdam, pp. 532-535. H. Rindermann; C. Flores-Mendoza; M. Mansur-Alves, Reciprocal effects between fluid and crystallized intelligence and their dependence on parents' socioeconomic status and education, Learning and Individual Differences, vol. 20, no. 5/2010, Amsterdam, pp. 544-548.

17 M. Birzer; D. Craig, Gender differences in police physical ability test performance, American Journal of Police, vol. 15, no. 2/1996, Bingley, pp. 93-108.

18 A. Chappell, Opus citatum, pp. 36-56.

[96] NBP • Žurnal za kriminalistiku i pravo 
the level of development of basic motoric abilities. Furthermore, the research is to determine whether in the selection model of the entrance exam at the ACPS there are differences between females and males in terms of the results achieved regarding all components of the entrance exam.

\section{Methods \\ Examinees sample}

1.576 examinees participated in the research, 39.4\% (621) of which were female and $60.6 \%$ (955) male. All candidates went through the process of selection and they enrolled the first year of the ACPS as the students of either basic academic or vocational studies. In the medical examination, body height $(\mathrm{BH})$ and body weight (BW) were measured as some of the selection criteria. For the needs of analysis of their success, sub-specimens were formed regarding their sex and the year of entering the ACPS, as shown in Table 1.

Table 1. The number of students, basic morphological characteristics and their proportional representation regarding their sex $i$ $n$ the period between 2012 and 2015

\begin{tabular}{|c|c|c|c|c|c|}
\hline & & 2012 & 2013 & 2014 & 2015 \\
\hline $\mathrm{N}$ & & 156 & 165 & 174 & 128 \\
\hline$\%$ & & 37.2 & 39.2 & 41.9 & 41.1 \\
\hline $\mathrm{BH}(\mathrm{cm})$ & & $1.70 \pm 0.05$ & $1.69 \pm 0.04$ & $1.70 \pm 0.05$ & $1.69 \pm 0.05$ \\
\hline BW (kg) & Ðี & $61.28 \pm 6.79$ & $61.42 \pm 6.25$ & $60.96 \pm 6.21$ & $60.10 \pm 5.82$ \\
\hline $\begin{array}{l}\text { BMI }(\mathrm{kg} / \\
\left.\mathrm{m}^{2}\right)\end{array}$ & $\stackrel{3}{3}$ & $21.15 \pm 1.67$ & $21.24 \pm 1.70$ & $21.21 \pm 1.69$ & $20.97 \pm 1.44$ \\
\hline $\mathrm{N}$ & & 263 & 258 & 241 & 191 \\
\hline$\%$ & & 62.8 & 60.2 & 58.1 & 59.9 \\
\hline $\mathrm{BH}(\mathrm{cm})$ & & $1.81 \pm 0.06$ & $1.82 \pm 0.06$ & $1.81 \pm 0.06$ & $1.82 \pm 0.07$ \\
\hline BW (kg) & & $77.89 \pm 8.54$ & $78.84 \pm 7.90$ & $78.89 \pm 8.61$ & $78.37 \pm 8.03$ \\
\hline $\begin{array}{l}\text { BMI }(\mathrm{kg} / \\
\left.\mathrm{m}^{2}\right)\end{array}$ & $\sum_{\Sigma}^{ \pm}$ & $23.53 \pm 1.71$ & $23.69 \pm 1.80$ & $23.86 \pm 1.88$ & $23.62 \pm 1.64$ \\
\hline
\end{tabular}




\section{Methods of measurement}

The research included all components of the entrance examination based on which the selection of candidates is made and whose results made entering the ACPS possible, which include:

1) High School Achievements (HSA). The number of points is calculated by adding the average marks at the end of the first, second, third and fourth grade of high school and then multiplied by two. The minimum could be 16 and the maximum 40 (http://www.kpa.edu.rs/cms/data/upis/informator-2013.pdf).

2) General Knowledge Test (GKT) provides for the candidate to get between 0 and 20 points. The testing is done with the use of information technology, and the test consists of a number of questions from different fields of human knowledge. The answers depict general education and awareness gained during the process of formal and non-formal education (http://www. kpa.edu.rs/cms/data/upis/informator-2013.pdf).

3) Serbian Language and Literature Test is evaluated at the scale ranging from 0 to 20 points. The testing is done with the use of information technology using a battery of tests reviewed by the Faculty of Philology, University of Belgrade (http://www.kpa.edu.rs/cms/data/upis/informator-2013.pdf).

4) The achievements in the Basic Motoric Abilities Assessment Test (BMA). General level of physical abilities is calculated with 7 basic motoric abilities tests using standardized methods. Thus calculated score ranges from 0 to 20 points. BMA is the eliminating test since the candidates with a score lower than 4 points do not fulfil the criteria for entering the ACPS. ${ }^{19}$

5) The total of points is calculated by adding all scores of all components of the entrance exam.

\section{Statistical methods}

The results were analysed by using basic descriptive statistical procedure. Central tendency measurements, minimal and maximal values and symmetrical distribution of the results were determined. Based on the average values, the equation of trend of change and R-squared are determined. The existence of the general variability differences between groups was determined by using MANOVA, while for the determination of partial differences between pairs of variables Bonferroni test was used. Statistical significance was defined at the

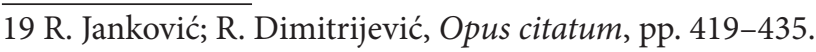

[98] NBP • Žurnal za kriminalistiku i pravo 
level of $\mathrm{p}<0.05 .^{20}$ For all statistical analyses software program IBM SPSS Statistics 22, ID: 729327 (premium faculty pack) was used.

\section{Results}

Table 2 shows the basic descriptive indictors of all components of the entrance exam at the ACPS achieved in the period between 2012 and 2015 for male and female candidates respectively.

Table 2. Basic descriptive indictors of the components of the entrance exam for all male and female candidates

\begin{tabular}{|c|c|c|c|c|c|c|c|}
\hline & & Mean & SD & Min. & Max. & Skew. & Kurt. \\
\hline HSA & \multirow{5}{*}{$\begin{array}{l}\text { चี } \\
\text { : } \\
3\end{array}$} & 35.05 & 3.77 & 20.52 & 40 & -0.926 & 0.683 \\
\hline SLLT & & 13.69 & 2.70 & 3 & 20 & -0.177 & -0.072 \\
\hline GKT & & 12.39 & 3.03 & 3.5 & 20 & -0.085 & -0.359 \\
\hline BMA & & 12.19 & 2.95 & 4.17 & 20 & 0.075 & -0.265 \\
\hline Total & & 73.33 & 7.45 & 42.18 & 94.24 & -0.228 & 0.914 \\
\hline HSA & \multirow{5}{*}{ 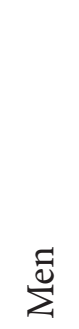 } & 33.23 & 4.24 & 18.30 & 40 & -0.418 & -0.394 \\
\hline SLLT & & 12.90 & 2.81 & 4 & 19 & -0.436 & 0.097 \\
\hline GKT & & 13.14 & 2.80 & 5.5 & 19.5 & -0.172 & -0.506 \\
\hline BMA & & 11.72 & 3.24 & 4.02 & 20 & -0.049 & -0.191 \\
\hline Total & & 70.98 & 7.55 & 37.67 & 93 & -0.492 & 1.118 \\
\hline
\end{tabular}

Table 3 shows the average values and standard deviation for male and female candidates at all components of the entrance exam regarding the year of entering.

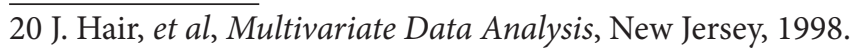

NBP • Journal of Criminalistics and Law [99] 
Radivoje Janković, Nenad Koropanovski

Table 3. Average values and standard deviation of number of points at all variables of the entrance exam for all male and female candidates regarding the year of entering

\begin{tabular}{|c|c|c|c|c|c|c|c|c|c|}
\hline & & \multicolumn{2}{|l|}{2012} & \multicolumn{2}{|l|}{2013} & \multicolumn{2}{|l|}{2014} & \multicolumn{2}{|l|}{2015} \\
\hline & & Mean & SD & Mean & SD & Mean & SD & Mean & SD \\
\hline HSA & & 34.56 & 4.19 & 35.40 & 3.67 & 34.93 & 3.86 & 35.37 & 3.17 \\
\hline SLLT & & 13.52 & 2.78 & 14.48 & 2.67 & 13.61 & 2.59 & 13.01 & 2.58 \\
\hline GKT & : & 12.28 & 3.37 & 12.82 & 2.79 & 12.50 & 2.99 & 11.83 & 2.92 \\
\hline BMA & हี & 11.36 & 3.06 & 12.74 & 2.88 & 11.89 & 2.76 & 12.94 & 2.90 \\
\hline Total & 3 & 71.72 & 8.53 & 75.44 & 7.19 & 72.92 & 7.02 & $\begin{array}{lll}73.16 \\
\end{array}$ & 6.32 \\
\hline HSA & & 32.53 & 4.46 & 33.58 & 4.10 & 33.26 & 4.04 & 33.73 & 4.27 \\
\hline SLLT & & 12.74 & 2.84 & 13.87 & 2.56 & 12.41 & 2.80 & 12.47 & \begin{tabular}{|l|}
2.79 \\
\end{tabular} \\
\hline GKT & & 12.85 & 3.05 & 13.31 & 2.63 & 13.20 & 2.58 & 13.25 & 2.92 \\
\hline BMA & $\Xi$ & 11.77 & 2.95 & 12.26 & 3.19 & 11.24 & 3.35 & 11.52 & 3.28 \\
\hline Total & $\sum$ & 69.89 & 7.62 & 73.02 & 5.86 & 70.12 & 7.04 & 70.98 & 7.73 \\
\hline
\end{tabular}

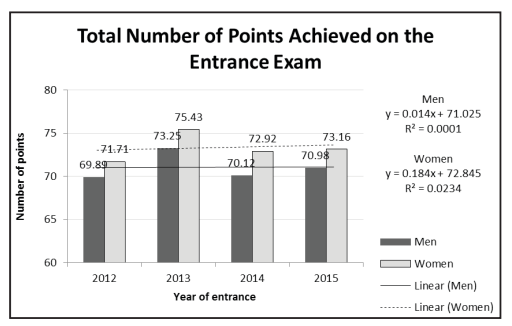

Figure 1. Trend of changes of the total number of points achieved at the entrance exam to the ACPS between 2012 and 2015 for men and women

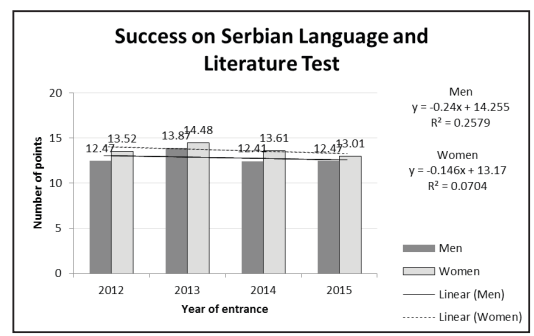

Figure 3. Trend of changes of the success on the Serbian Language and Literature Test between 2012 and 2015 for men and women

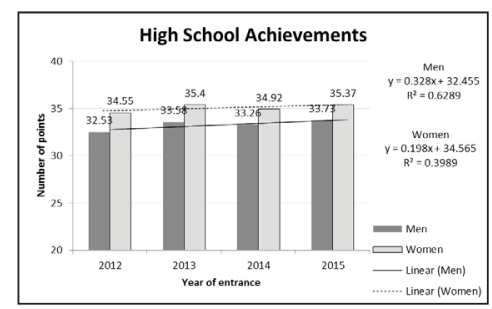

Figure 2. Trend of changes of the high school achievements between 2012 and 2015 for men and women

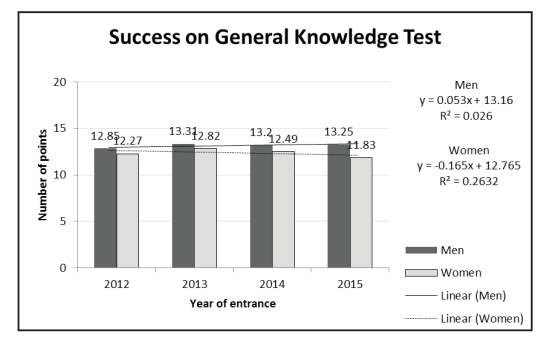

Figure 4. Trend of changes of the success on the General Knowledge Test between 2012 and 2015 for men and women

[100] NBP • Žurnal za kriminalistiku i pravo 


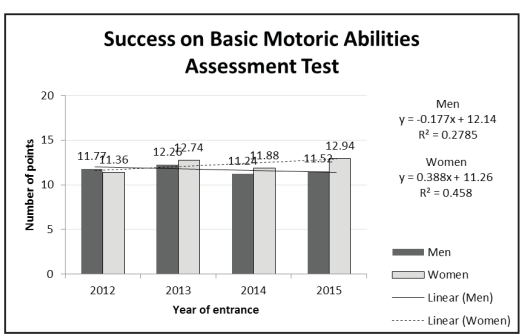

Figure 5. Trend of changes of the success on the Basic Motoric Abilities Assessment Test between 2012 and 2015 for men and women

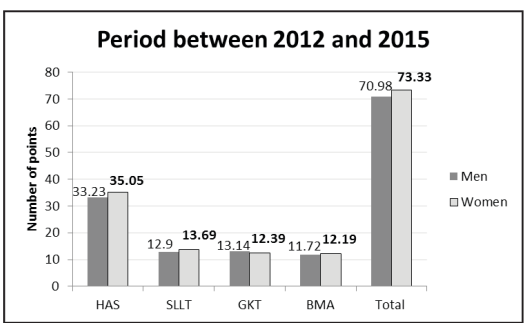

Figure 6. Graphic presentation of differences of the components of the entrance exam between men and women.

The differences between all the candidates (621 women and 955 men) who entered the ACPS in the period from 2012 to 2015 were analysed using MANOVA. It was determined that that on a general level in Wilks Lambda's value of 0.910 , there is a statistically significant difference between the sexes $(\mathrm{F}=38.080, \mathrm{p}<0.05)$. Women achieved 1.82 points higher result on HSA $(\mathrm{F}=$ $74.951, \mathrm{p}<0.05), 0.79$ points more on SLLT $(\mathrm{F}=30.639, \mathrm{p}<0.05), 0.47$ points more on BMA assessment $(\mathrm{F}=9.329, \mathrm{p}=0.002)$, while their results were lower by 0.71 points on GKT $(\mathrm{F}=25.102, \mathrm{p}<0.05)$. Moreover, women scored 2.35 points more in total number of points $(\mathrm{F}=17.025, \mathrm{p}<0.05)$.

Further analysis revealed differences in success at the entrance exam between men and women regarding the year of entrance the ACPS. Using Bonferroni test statistically significant difference was determined in HSA and the total number of points during the observed period. In SLLT significant difference was found from 2012 to 2014. During the first two years there were no differences between men and women in GAK and BMA. However, for these two variables statistically significant difference was found in 2013 and 2014. The differences in results and statistical significance are shown on Table 4

Table 4. Differences between men and women in success in individual components at the entrance exam between 2012 and 2015

\begin{tabular}{|l|l|l|l|l|l|l|l|l|l|l|l|l|}
\hline & \multicolumn{3}{|l}{2012} & \multicolumn{3}{l}{2013} & \multicolumn{3}{l|}{2014} & \multicolumn{2}{l|}{2015} & \\
\cline { 2 - 15 } & aps. & rel. & p & aps. & rel. & p & aps. & rel. & p & aps. & rel. & p \\
\hline HSA & 2.03 & 6.24 & $<0.05$ & 1.82 & 5.42 & $<0.05$ & 1.67 & 5.02 & $<0.05$ & 1.64 & 4.86 & $<0.05$ \\
\hline SLLT & 0.78 & 6.12 & 0.006 & 0.61 & 4.40 & 0.020 & 1.2 & 9.67 & $<0.05$ & 0.54 & 4.33 & 0.070 \\
\hline GKT & -0.57 & -4.44 & 0.076 & -0.49 & -3.68 & 0.068 & -0.7 & -5.30 & 0.011 & -1.42 & -10.72 & $<0.05$ \\
\hline BMA & -0.41 & -3.48 & 0.223 & 0.48 & 3.92 & 0.124 & 0.65 & 5.78 & 0.032 & 1.42 & 12.33 & $<0.05$ \\
\hline Total & 1.83 & 2.62 & 0.017 & 2.42 & 3.31 & $<0.05$ & 2.8 & 3.99 & $<0.05$ & 2.18 & 3.07 & 0.006 \\
\hline
\end{tabular}




\section{Discussion}

The MANOVA results demonstrated that generally there is a statistically significant difference between all men and women who entered the ACPS in the period from 2012 to 2015. It was determined that women achieved 5.48\%, $6.12 \%$ and $4.01 \%$ statistically better results for HSA, SLLT and BMA variables, respectively. Their results were 5.71\% lower than men's on GKT. However, when total entrance exam results are taken into account, women achieved $3.31 \%$ statistically better score within this period (Figure 6). In further analysis which was to determine the differences in entrance examination success for each individual generation, it is noticeable that every year women had statistically significant better HSA and the total number of points. They also achieved better results in SLLT in the period between 2012 and 2014, while in 2015 the difference was close to the level of statistical significance $(p=0.070)$. BMA results, namely the score in points, did not show statistically significantly variation in the first observed two generations. However, in 2014 and 2015, women had statistically significantly higher number of points compared to men (Table 4).

Better High School Achievements demonstrated by women had been expected when earlier researches were considered. It has been determined that girls in Serbia have better marks both in lower and higher grades of school, and the reason for that may be their higher sensibility and sense of responsibility. ${ }^{21}$ However, an opposite effect had been observed regarding GKT. The men demonstrated statistically significantly better results in the last two observed generations and in the total sample. Since women achieve better results in HSA and SLLT, the reason for their less superior GKT results could be the structure of questions which potentially refer to male candidates' field of interest (e.g. sport). Furthermore, for BMA and SLLT the fields that require preparation have been defined, while GKT has been structured to a lesser degree, hence the difference in preparation for this field. Moreover, as Šarčević and Vasić ${ }^{22}$ defined, a school grade should reflect a level and quality of institutional education within a community (which is a precondition for the community's development) and individually gained knowledge (an indicator of personal development). Along with this, it would seem realistic that the individuals with better school achievements should achieve better results in all the tests. However, a school grade in the national educational system is based largely on the teacher's individual assessment, and not on objective indicators, which

21 A. Trogrlić; D. Šarčević; A. Vasić, Pol, školski uspeh i motivacija za školsko učenje, Pedagoška stvarnost, vol. 59, no. 2/2013, Novi Sad, pp. 332-349. D. Šarčević; A. Vasić, Sociodemografski i psihološki korelati školskog uspeha, Primenjena psihologija, vol. 7, no. 3/2014, Novi Sad, pp. 401-427.

22 D. Šarčević; A. Vasić, Opus citatum, pp. 401-427.

[102] NBP • Žurnal za kriminalistiku i pravo 
could also, to some extent, explain the difference between HSA and SLLT results on the one hand, and GKT results on the other.

The research so far that dealt with trends of changes of BMA at the entrance exam in the period between 2011 and 2014 determined a negative trend of all analysed physical abilities tests ${ }^{23}$ in men. On the other hand, women displayed a positive trend of changes at four out of seven Physical Abilities tests. ${ }^{24}$ The found trend of changes of individual BMA test has an impact on the total number of points, hence the statistically significantly better results of women in the last two observed generations was expected. Furthermore, the number of female candidates entering the ACPS as tuition-free students has not been limited since 2014 (previously the maximum number was 30), which could also be the reason of better BMA results. Apart from that, every year a higher percentage of women apply for the ACPS (33.87\%, 34.75\%, 37.32\% and 27.28\%, respectively) and the competition (and better potential preparation for the entrance examination with it) might influence the more superior results.

Different study programs are realized at the ACPS within which the students gain practical knowledge and the skills necessary for doing police work. Although different in content and methods, the goal of the programs is mutual - obtaining necessary practical knowledge and skills which will enable professional competence. For the students of the ACPS to handle the programs efficiently, it is desirable to separate those with adequate psychophysical characteristics. ${ }^{25}$ However, the selection of candidates with the desirable traits poses a constant challenge. The main reason for this is the difficulty to precisely measure the police performance quality and to determine which traits and abilities could condition it. ${ }^{26}$ However, the research conducted by Annell et al. ${ }^{27}$ supports a multi-dimensional selection model where cognitive abilities are checked, conscientiousness, emotional stability, and agreeableness are assessed as well as the general fitness level. The justifiability of the level of physical characteristics development check lies in the fact that a variety of tasks that characterize police work highlights the importance of police officers being in good physical condition..$^{28}$ Naturally, in the process of assortment of tests that cover fitness level as a selection criterion, it would be desirable to ensure that

23 N. Koropanovski; R. Dimitrijevic; R. Jankovic, Opus citatum, pp. 136-143

24 N. Koropanovski; R. Jankovic; R. Dimitrijevic, Trend of changes in motor abilities initial level at the police academy female students, in: International Scientific Conference "Effects of Physical Activity Application to Anthropological Status with Children, Youth and Adults", Belgrade, 2015, pp. 142-143.

25 S. Milojević; B. Janković; V. Cvetković, Prediction model of effective studies at the academy of criminalistic and police studies, NBP - Journal of Criminalistics and Law, vol. 20, no. $1 / 2015$, Belgrade, pp. 135-149.

26 B. Sanders, Opus citatum, pp. 313-328. M. White, Opus citatum, pp. 27-49.

27 S. Annell; P. Lindfors; M. Sverke, Opus citatum, pp. 221-238

28 M. Strating, et al, Opus citatum, pp. 255-260. 
the tests are based on bona fide occupational requirements or bona fide occupational qualifications. ${ }^{29}$

The school achievements present an advantage for the candidates with developed work abilities. ${ }^{30}$ The learning habit and the accumulation of knowledge which are supposed to be highlighted on GKT, SLLT along with the High School Achievements might be defined as a measure of general and individual achievements and have a firm positive correlation with effective studies' results. ${ }^{31}$ Moreover, based on the White's researches, ${ }^{32}$ it was determined that writing and communication are two critically important skills that are prerequisites for good policing. Reading level is typically related to writing and communications skills thereby increasing its relevance to the recruitment, selection, and training processes. In the research conducted by Milojević et al..$^{33}$ effective studies at the ACPS predictors were defined. It was observed that a potential for successful studies is increased if the candidates graduated from a grammar school or a high school of natural sciences, or if they do sports. In other words, the candidates with a broader general education and more developed learning habits, together with more developed BMA, could acquire the studies' program better, which, along with the afore mentioned researches from the field of selection matter, confirms the adequacy of multi-dimensional selection system of the ACPS.

Theoretically, on the first level of selection the candidates of inadequate health state and inappropriate psychological characteristic are eliminated from the population who applied for the Academy. On the second level, those with the developed working habits from the aspect of intellectual and work abilities are selected, which could be represented by HSA. Moreover, the candidate with developed learning abilities and broader knowledge are expected to score more points on SLLT and GKT. The last selection level is conducted by integral level of BMA development assessment, where a current maximum level of physical abilities of the candidates is assessed, all displayed with the use of point scoring with an elimination level of 4 points. ${ }^{34}$

A positive trend of changes in both sexes is determined for HSA (Figure 2), and a negative one for SLLT (Figure 3). Women display a positive BMA trend and a negative GKT, while in males an opposite trend was observed (Figure 4 and Figure 5). Nevertheless, despite the different trends on individual tests, the total number of points achieved at the entrance examination has a positive

29 G. A. Anderson; D. Plecas; T. Segger, Opus citatum, pp. 8-31.

30 M. Dopsaj; M. Blagojević; G. Vučković, Opus citatum, pp. 166-183.

31 Z. Kranjaić, Intelektualna nadarenost mladih, Beograd, 2002.

32 M. White, Opus citatum, pp. 27-49.

33 S. Milojević; B. Janković; V. Cvetković, Opus citatum, pp. 135-149.

34 R. Janković; R. Dimitrijević, Opus citatum, pp. 419-435. M. Dopsaj; M. Blagojević; G. Vučković, Opus citatum, 166-183. 
trend of changes for both populations. Hypothetically speaking, based on the variable trend equation, in the forthcoming period an increased number of points in candidates entering the ACPS could be anticipated. The mentioned increase could be more prominent in female candidates who, in the trend of changes equation, have a coefficient of +0.184 compared to males whose coefficient measures to +0.014 (Figure 1). Along with the fact that the total number of candidates applying for the ACPS is decreasing, ${ }^{35}$ in the mentioned period it could be observed that there are a larger percentage of women and a lower of percentage of men entering the Academy (Table 1). In the process of selection the candidates of the best quality are chosen from a larger specimen, which could be another reason for a large positive trend of changes in women.

For the process of selection to be successful, it is necessary to determine the upper limit compared to the percentage distribution, ${ }^{36}$ namely, in the process of entrance exams, thresholds may impair the predictive power of selection methods. ${ }^{37}$ In previous researches that dealt with the BMA trend of changes analysis at the entrance exam at the APCS, it was determined that one of the reasons of the negative variable trend was the low elimination level of 4 points. ${ }^{38}$ Furthermore, the research determined that the mentioned threshold was one of the reasons of insufficient influence of the special physical education course on BMA. ${ }^{39}$ On the basis of earlier research, in order to select the best candidates from the population that applied to the ACPS, and in order for them to deal with the special physical education program more successfully, the threshold for BMA was raised to eight points in 2016. The named change is to eliminate the candidates with inadequate physical abilities and thus make the selection process more efficient. Furthermore, it would be justifiable to anticipate a change in the determined negative BMA trend in males in upcoming generations.

\section{Conclusion}

The research determined that there are differences in the total number of points achieved at the entrance exam of the APCS between men and women. It was demonstrated that the women achieve statistically significantly better

35 N. Koropanovski; R. Jankovic; R. Dimitrijevic, Opus citatum, pp. 142-143. 36 S. Fajgelj, Psihometrija: Metod i teorija psihološkog merenja, Beograd, 2003. 37 S. Annell; P. Lindfors; M. Sverke, Opus citatum, pp. 221-238.

38 N. Koropanovski; R. Dimitrijevic, R. Jankovic, Opus citatum, pp. 136-143.

39 M. Dopsaj; M. Blagojević; G. Vučković, Opus citatum, pp. 166-183. R. Janković, et al, Opus citatum, pp. 316-322. R. Dimitrijević, et al, The influence of different physical education programe on police students' physical abilities, Policing: An International Journal of Police Strategies \& Management, vol. 37, no. 4/2014, Bingley, pp. 794-808. 
HSA results as well as on the SLLT and BMA. Worse result in women is determined on GKT. Regardless of the worse GKT results in the course of the observed period, women achieved $3.31 \%$ statistically significantly greater success in the overall score.

By the trend of changes analysis, it was determined that every year candidates with increasingly better high school achievements enter the Academy, but that the results at the Serbian Language and Literature Test declined. On the Basic Motoric Abilities Assessment Test a positive trend of changes was determined in women and a negative one in men. On the tests for assessment of General Knowledge, it was observed that men have a positive trend compared to women. The reasons of the obtained results could be the following: 1 . An increase in percentage of women who apply for and who enter the APCS in the observed period; 2 . Characteristics of sexes in relation to sensibility and the sense of responsibility towards education; 3 . GKT structure of questions; 4. The way of scoring general physical readiness and a low elimination threshold on the BMA assessment test.

Based on the research, it can be concluded that it is necessary to conduct changes in the preparation system and evaluation on SLLT in order to stop the negative trend observed in both sexes. Moreover, it is necessary to determine the exact reasons of the difference in trend of changes and in GKT success between men and women. In additional researches it is necessary to determine if the threshold changes for the BMA will influence the trend and the differences in the number of points between the sexes. Moreover, after the results monitoring, an evaluation of tests and the formula of general physical readiness assessment of the candidates could be potential.

\section{References}

1. Anderson, G. A; Plecas, D; Segger, T; Police officer physical ability testing: Re-validation a selection criterion, Policing: An International Journal of Police Strategies \& Management, vol. 24, no. 1/2001, Emerald, Bingley.

2. Anderson, S. G; Plecas, D; Predicting shooting scores from physical performance data, Policing: An International Journal of Police Strategies \& Management, vol. 23, no. 4/2000, Emerald, Bingley.

3. Annell, S; Lindfors, P; Sverke, M; Police selection - implications during training and early career, Policing: An International Journal of Police Strategies \& Management, vol. 38, no. 2/2015, Emerald, Bingley.

[106] NBP • Žurnal za kriminalistiku i pravo 
4. Batey, M; Furnham, A; Safiullina, X; Intelligence, general knowledge and personality as predictors of creativity, Learning and Individual Differences, vol. 20, no. 5/2010, Elsevier, Amsterdam.

5. Birzer, M; Craig, D; Gender differences in police physical ability test performance, American Journal of Police, vol. 15, no. 2/1996, Emerald, Bingley.

6. Chappell, A; Police academy training: comparing across curricula. Policing: An International Journal of Police Strategies \& Management, vol. 31, no. 1/2008, Emerald, Bingley.

7. Dimitrijević, R; Koropanovski, N; Dopsaj, N; Vučković, G; Janković, R; The influence of different physical education program on police students' physical abilities, Policing: An International Journal of Police Strategies \& Management, vol. 37, no. 4/2014, Emerald, Bingley.

8. Dopsaj, M; Blagojević, M; Vučković, G; Normativno-selekcioni kriterijum za procenu bazično motoričkog statusa kandidata za prijem na studije Kriminalističko-policijske akademije u Beogradu, Bezbednost, vol. 49, no. 4/2007, MUP Republike Srbije, Beograd.

9. Fajgelj, S; Psihometrija: Metod i teorija psihološkog merenja, Centar za primenjenu psihologiju, Beograd, 2003.

10. Hair, J; Anderson, R; Tatham, R; Black, W. Multivariate Data Analysis, Prentice - Hall, New Jersey, 1998.

11. Janković, R; Dimitrijević, R; Stanje i mogućnosti unapređenja načina procene motoričkih sposobnosti u sistemu Ministarstva unutrašnjih poslova Republike Srbije, Kultura polisa, vol. 9, no. 1/2012, Kultura - Polis, Institut za Evropske studije, Novi Sad.

12. Janković, R; Dimitrijević, R; Vučković, G; Koropanovski, N; Academy of criminalistic and police studies candidates' basic-motor skills in function of successful enter exam for basic academic studies, in: International Scientific Conference: Effects of Physical Activity Application to Anthropological Status With Children, Youth and Adults - Thematic conference proceedings of international significance, Faculty of Sport and Physical Education, Belgrade, Decembre 2013.

13. Koropanovski, N; Dimitrijevic, R; Jankovic, R; Trend of changes in motor abilities initial level in the male students of the Academy of Criminalistic and Police Studies, in: International Scientific Conference "Archibald Reiss Days", Academy of Criminalistic and Police Studies, Belgrade, 2016.

14. Koropanovski, N; Jankovic, R; Dimitrijevic, R; Trend of changes in motor abilities initial level at the Police Academy female students, in: International Scientific Conference "Effects of Physical Activity Application to Anthropological Status with Children, Youth and Adults", Faculty of Sport and Physical Education, Belgrade, 2015. 
15. Kranjaić, Z; Intelektualna nadarenost mladih, Institut za psihologiju, Beograd, 2002.

16. Lonsway, K. A; Tearing down the wall: Problems with consistency, validity, and adverse impact of physical agility testing in police selection, Police Quarterly, vol. 6, no. 3/2003, SAGE Publications, London.

17. Lord, V; Swedish police selection and training: issues from a comparative perspective, Policing: An International Journal of Police Strategies \& Management, vol. 21, no. 2/1998, Emerald, Bingley.

18. Metchik, E; An analysis of the „Screening out" model of police officer selection, Police Quarterly, vol. 2, no. 1/1999, SAGE Publications, London.

19. Milojević, S; Janković, B; Cvetković, V; Prediction model of effective studies at the academy of criminalistic and police studies, NBP - Journal of Criminalistics and Law, vol. 20, no. 1/2015, Academy of Criminalistic and Police Studies, Belgrade.

20. Rindermann, H; Flores-Mendoza, C; Mansur-Alves, M; Reciprocal effects between fluid and crystallized intelligence and their dependence on parents' socioeconomic status and education, Learning and Individual Differences, vol. 20, no. 5/2010, Elsevier, Amsterdam.

21. Sanders, B; Maybe there's no such thing as a "good cop": Organizational challenges in selecting quality officers, Policing: An International Journal of Police Strategies \& Management, vol. 26, no. 2/2003, Emerald, Bingley.

22. Strating, M; Bakker, R; Dijkstra, G; Lemmink, K; Groothoff, J.W; A job-related fitness test for the Dutch police, Occupational Medicine, vol. 60, no. 4/2010, Oxford University Press, Oxford.

23. Šarčević, D; Vasić, A. Sociodemografski i psihološki korelati školskog uspeha, Primenjena psihologija, vol. 7, no. 3/2014, Filozofski fakultet, Novi Sad.

24. Trogrlić, A; Šarčević, D; Vasić, A; Pol, školski uspeh i motivacija za školsko učenje, Pedagoška stvarnost, vol. 59, no. 2/2013, Pedagoško društvo Vojvodine, Novi Sad.

25. White, M; Identifying Good Cops Early Predicting Recruit Performance in the Academy, Police Quarterly, vol. 11, no. 1/2008, SAGE Publications, London.

26. http://www.kpa.edu.rs/cms/data/upis/informator-2013.pdf 


\title{
TREND PROMENA REZULTATA NA PRIJEMNOM ISPITU STUDENATA KRIMINALISTIČKO-POLICIJSKE AKADEMIJE ${ }^{40}$
}

\author{
Radivoje Janković \\ Nenad Koropanovski \\ Kriminalističko-policijska akademija, Beograd
}

Sažetak: Cilj ovog istraživanja bio je da utvrdi trendove promena komponenti prijemnog ispita na Kriminalističko-policijskoj akademiji (KPA). Takođe, ovaj rad bi trebalo da utvrdi da li postoje razlike između polova u odnosu na uspeh postignut na prijemnom ispitu. U istraživanju je učestvovalo 1.576 ispitanika, od čega 39,4\% (621) žena i 60,6\% (955) muškaraca, koji su se upisali na KPA kao studenti osnovnih akademskih ili strukovnih studija. Istraživanje je obuhvatilo sve komponente prijemnog ispita na osnovu kojih se vrši selekcija kandidata: uspeh u srednjoj školi (UŠ), test opšte informisanosti (TOI), test znanja iz srpskog jezika i književnosti (SR), nivo razvijenosti bazičnih motoričkih sposobnosti (BMS) i ukupan broj bodova ostvaren na prijemnom ispitu. Rezultati su analizirani primenom osnovne deskriptivne statističke procedure. Utvrđene su mere centralne tendencije, minimalne i maksimalne vrednosti i pravilnosti rasporeda rezultata. Na osnovu prosečnih vrednosti ustanovljena je jednačina trenda promena uz $R$-squared. Za utvrđivanje postojanja statistički značajne razlike na generalnom nivou korišćena je MANOVA, dok su parcijalne razlike između grupa ustanovljene Bonferonijevim testom. Statistička značajnost određena je na nivou od $\mathrm{p}<0,05$. Rezultati su pokazali da postoji pozitivan trend promena kod oba pola za UŠ i negativan za SR. Kod žena je ustanovljen pozitivan trend BMS, ali negativan TOI. Međutim, kod muškaraca utvrđena suprotna pojava.

Pored različitih trendova pojedinačnih testova, ukupan broj bodova ostvaren na prijemnom ispitu ima pozitivan trend promena za obe populacije. Hipotetički posmatrano, u narednom periodu može se očekivati da će se povećati prosečan broj bodova kandi-

$40 \mathrm{Rad}$ je rezultat istraživanja na projektu „Upravljanje policijskom organizacijom u sprečavanju i suzbijanju pretnji bezbednosti u Republici Srbiji“, koji finansira i realizuje Kriminalističko-policijska akademija u Beogradu, ciklus naučnih istraživanja 2015-2019. godine. 
data koji će biti upisani na KPA. Navedeno povećanje moglo bi biti izraženije kod kandidata ženskog pola koji u jednačini trenda promena imaju koeficijent $+0,184$ u odnosu na muškarce kod kojih izračunati koeficijent iznosi $+0,014$. Rezultati MANOVA su pokazali da na generalnom nivou između svih upisanih muškaraca i žena na KPA postoji statistički značajna razlika. Ustanovljeno je da su žene ostvarile statistički bolje rezultate za varijable UŠ, SR i BMS za 5,48\%, 6,12\% i 4,01\%, respektivno. Lošiji rezultat ostvarile su na TOI za $5,71 \%$. Međutim, kada se posmatra ukupan rezultat prijemnog ispita, žene su u ovom periodu imale statistički bolji skor za 3,31\%. U daljoj analizi ustanovljeno je da su žene svake godine imale statistički značajno bolji UŠ i ukupan broj bodova. Bolje rezultate su ostvarile i na SR u periodu od 2012. do 2014, dok je 2015. godine razlika bila blizu nivoa statističke značajnosti. Razlike u BMS pojavile su se 2014. i 2015. godine - žene su imale statistički značajno veći broj bodova. Na osnovu ovog istraživanja može se zaključiti da je potrebno izvršiti izmene sistema pripreme i evaluacije SR u cilju zaustavljanja negativnog trenda kod oba pola. Takođe, potrebno je utvrditi tačne razloge različitog trenda promena i uspeha u TOI između muškaraca i žena.

Ključne reči: policija, selekcija, prijemni ispit, trend promena. 